Brit. J. industr. Med., 1963, 20, 47.

\title{
FATAL ADDICTION TO TRICHLOROETHYLENE
}

\author{
BY \\ W. R. L. JAMES \\ From the Department of Pathology and Bacteriology, \\ Welsh National School of Medicine, Cardiff
}

(RECEIVED FOR PUBLICATION JULY 16, 1962)

\begin{abstract}
Trichloroethylene inhalation is a common industrial hazard that involves a risk of addiction. In the present case there was evidence of indulgence of addiction at work but not at home. The medical history suggested permanent paresis of the olfactory nerves in addition to intermittent gastric disturbance. Sudden death, not preceded by severe physical exertion, occurred some 17 hours after the last known exposure to the vapour.

There was fatty degeneration of the liver and old and recent lung haemorrhages. Trichloroethylene was isolated from the tissues. The urine contained a large amount of trichloroacetic acid.
\end{abstract}

\section{Case Report}

A man of 31 had been employed for nine years in an electroplating works. Latterly he had been foreman of the electroplating shop. The shop, measuring $48 \times 45 \times$ $11 \mathrm{ft}$., contained a pair of heated trichloroethylene degreasing vats each measuring $28 \times 48 \times 60$ in. high. Before chromium plating, metal articles were degreased by suspending them in the vapour above the hot trichloroethylene. The vats were cleaned out once a week by scraping out sludge through small doors fitted at their bases.

In 1948 he was found unconscious in a vat that contained wet sludge. He recovered after two days in hospital. He said he had got into the tank to clean it, and he was rebuked by his manager for doing so. Some years later he was again found in a vat, this time fully conscious, and he was again reminded that his actions were contrary to the safety regulations. In 1957, about six months before death, he was again found in a vat and on this occasion he was warned that he would be discharged if it happened again. From time to time he had been seen leaning over full tanks for as long as 10 minutes at a time, without any occupational reason for doing so.

During the year preceding death his manager noticed that he seemed to be more affected by fumes than were his fellow employees. He had bouts of lethargy, his speech was sometimes slurred, and he was occasionally unsteady on his feet. His wife noticed that he had lost his sense of smell-he could not even smell cleaning ammonia. On reaching home after work he sometimes vomited, declined food, and was drowsy. She said that these symptoms occurred only after he had been helping to clean out the vats at work.

In spite of occasional malaise he worked regularly and on July 10, 1957 during three hours of evening overtime work he helped to clean the sludge from one of the vats. He then rode 12 miles on a motorcycle and on reaching home he vomited, declined food, and went to bed. At 7 a.m. the next morning he looked pale but said he felt "all right" and motorcycled to his work. From 8 a.m. to about noon he did his usual supervisory work in the plating shop during which he was no more exposed to vapour than were the other employees. At about 12 noon he went upstairs to a storeroom where he helped a woman employee to move some small light packages. He made no complaint of illness but at about 1.30 p.m. he suddenly fell to the floor and died almost immediately.

The body was stored in a refrigerator until the autopsy 21 hours later.

Autopsy.-Height $5 \mathrm{ft} .10$ in. $(178 \mathrm{~cm}$.); weight $10 \mathrm{st}$. $12 \mathrm{lb}$. (69 kg.). On the forehead there was an abrasion consistent with his terminal collapse.

The bronchi contained thick mucus. The stomach contained a small amount of partly digested food. There were scanty small haemorrhages in the gastric mucosa.

The gross appearance of the heart, brain, liver, and all the other organs was normal.

None of the organs smelled of trichloroethylene. In particular there was no smell of it in the stomach.

Microscopy.-Pieces of the heart, brain, lung, liver, and kidneys were examined histologically.

In the lungs there were numerous small recent haemorrhages into the air spaces. In some of the air spaces and in the interstitial tissue there were clusters of haemosiderin-laden macrophages (Fig. 1).

The liver showed numerous small foci of fatty degeneration of mid-zonal distribution (Fig. 2).

The sections of myocardium, brain, and kidney appeared normal. 


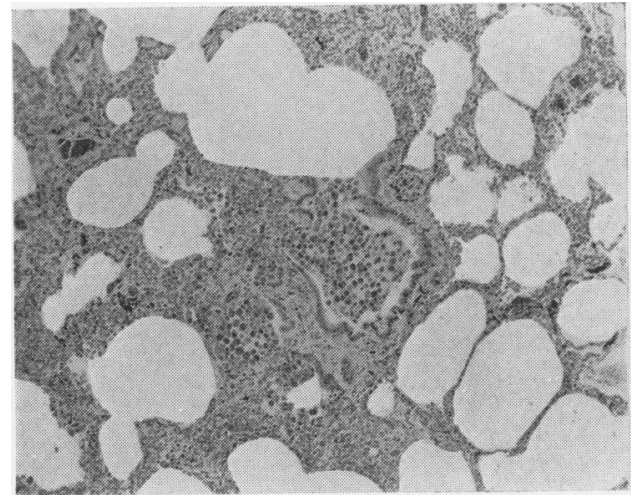

Fig. 1.-The lung section shows small recent haemorrhages and clusters of haemosiderin-laden macrophages. $(\times 40)$

Chemistry.-Analysis of the tissues for trichloroethylene yielded the following results. Right heart blood: $2.25 \mathrm{mg}$. $/ 100 \mathrm{ml}$.; stomach and contents, a total of $19.9 \mathrm{mg}$.; small intestine and contents, a total of $14.9 \mathrm{mg}$.; and liver, a total of $7 \cdot 1 \mathrm{mg}$.

The urine contained $55.5 \mathrm{mg}$. of trichloroacetic acid per $100 \mathrm{ml}$.

\section{Discussion}

For the following reasons death was attributed to trichloroethylene poisoning.

1. No other cause of sudden death was found.

2. Trichloroethylene inhalation is known to cause cardiac arrhythmia (Norris and Stuart, 1957; Nowill, Stephen, and Searles, 1953; Ostlere, 1953; von Oettingen, 1958).

3. Published material contains references to sudden death under similar circumstances (Chief Inspector of Factories, 1954; Gonzales, Vance, Helpern, and Umberger, 1954; Kleinfeld and Tabershaw, 1954).

4. Trichloroethylene was found in the blood in significant amount.

5. The urinary trichloroacetic acid concentration suggested recent exposure to high concentrations of trichloroethylene vapour.

6. The symptoms accorded with intermittent trichloroethylene poisoning.

Gonzales et al. (1954) refer to sudden death two hours after exposure. In the present case the interval was 17 hours. During this time the deceased had ridden a motorcycle, slept, and done a morning's work. It is possible that death was due to the accumulation of breakdown products rather than to the trichloroethylene itself.

Different opinions have been expressed regarding the effect on the liver. Graber (1950), Grandjean, Münchinger, Turrian, Haas, Knoepfel, and Rosen-

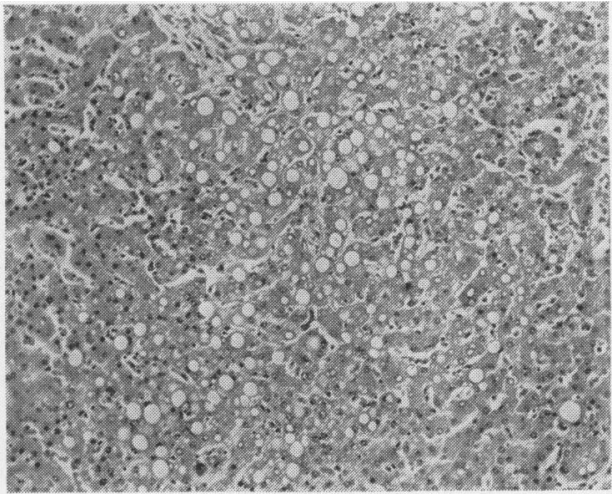

FIG. 2.-The small foci of fatty degeneration were not constantly related either to the bile ducts or to the centrilobular veins. $(\times 80)$

mund (1955), Seifter (1944), and Willcox (1934) found evidence of liver damage. Stüber (1931), Gonzales et al. (1954), and Browning (1952) considered that the liver was unaffected, while Teare (1948) did not report any liver changes in his account of a fatality. The present case involved a teetotaller with no other apparent cause for hepatic fatty changes. The foci of degeneration were small but by no means difficult to detect. The changes were much less severe than would have been expected after comparable exposure to chloroform or carbon tetrachloride.

The pulmonary haemosiderosis accords with haemorrhage some days before death. The recent haemorrhages might well have occurred at the time of death. Teare (1948) observed similar small pulmonary haemorrhages in a boy of 16 who died while he was inhaling vapour.

Blood levels of 5 to $10 \mathrm{mg} . / 100 \mathrm{ml}$. cause anaesthesia (Powell, 1945). Normally the drug is rapidly excreted by processes involving the liver, lungs, and kidney. The $2.25 \mathrm{mg}$. $/ 100 \mathrm{ml}$. found 17 hours after exposure in this case suggests slow detoxication and excretion. The autopsy findings did not provide any adequate organic reason for slow excretion.

Part of the trichloroethylene is changed to trichloroacetic acid and excreted in the urine. There is evidence to suggest a correlation between the atmospheric concentration of the inhaled vapour, the severity of symptoms, and the subsequent urinary trichloroacetic acid concentration (Browning, 1953; Elkins, 1950). The very high concentration of $55.5 \mathrm{mg} .100 \mathrm{ml}$. indicates recent exposure to a high vapour concentration. Stewart and Stolman (1960) showed that the maximum urinary concentration was reached some 24 hours after inhalation. On this basis the urinary level in the 
present case accords with severe exposure the day before death.

In spite of the presence of $19.9 \mathrm{mg}$. in the stomach the contents did not smell of trichloroethylene. The smell of the liquid is by no means pungent and if only a small amount is present the odour may be masked by that of the other contents. It was suggested that the $19.9 \mathrm{mg}$. indicated that the deceased had drunk some shortly before death. This suggestion was abandoned when it was pointed out that his terminal illness bore no resemblance to the clinical syndromes of known cases of trichloroethylene drinking (Stentiford and Logan, 1956; Stephens, 1945). It is likely that the small amount found reached the stomach in swallowed contaminated air and saliva.

\section{Litigation}

The widow applied to the court for compensation. The evidence satisfied the court that the deceased was an addict. It was found that the employers were negligent in ignoring the evidence of addiction and in failing to seek the advice of the factory doctor and inspector. Damages of $£ 7,000$ were reduced to $£ 5,250$ because of the employee's contributory negligence (Brit. med. J., 1961). Notice of appeal was given. Appeal was allowed, and their Lordships decided that the work itself could all be performed in perfect safety if the regulations were complied with. The employer was under no duty to deprive him of his employment because he was not prepared to take care of himself in circumstances where he could well have done so (Times Law Reports, 1961).

I am indebted to Professor Gough of this department for advice and criticism, and to Mr. Gerald Tudor, H.M. Coroner for the City of Cardiff, for permission to publish much of the information. Mr. W. M. Travers took the photographs.

\section{REFERENCES}

Brit. med. J. (1961). Medico-Legal, 1, 1550

Browning, E. (1952). Toxicity of Industrial Organic Solvents. M.R.C. Industr. Health Research Board Rpt No. 80, p. 169 - (1953). Toxic Solvents, $\mathfrak{p}$. 66. Arnold, London.

Chief Inspector of Factories (1954). Annual Report for 1952, p. 144. H.M.S.O., London.

Elkins, H. B. (1950). The Chemistry of Industrial Toxicology, p. 143. Wiley, New York.

Gonzales, T. A., Vance, M., Helpern, M., and Umberger, C. J. (1954). Legal Medicine Pathology and Toxicology, 2nd ed.,

p. 792. Appleton-Century-Crofts, New York.
Graber, H. (1950). Dtsch. Z. ges. gerichtl. Med., 40, 88.

Grandjean, E., Münchinger, R., Turrian, V., Haas, P. A., Knoepfel, H.-K., and Rosenmund, H. (1955). Brit. J. industr. Med., 12,131 .

Kleinfeld, M.; and Tabershaw, I. R. (1954). Arch. industr. Hyg., $10,134$.

Norris, W., and Stuart, P. (1957). Brit. med. J., 1, 860.

Nowill, W. K., Stephen, C. R., and Searles, P. W. (1953). Arch. Surg., 66, 35.

Ostlere, G. (1953). Trichloroethylene Anaesthesia, p. 26. Livingstone, Edinburgh.

Powell, J. F. (1945). Brit. J. industr. Med., 2, 142

Seifter, J. (1944). J. industr. Hyg., 26, 250.

Stentiford, H. B., and Logan, C. J. H. (1956). Lancet, 2, 659.

Stephens, J. A. (1945). Brit. med. J., 2, 218.

Stewart, C. P., and Stolman, A. (1960). Toxicology, Vol 1, p. 38. Ácademic Press, New York and London.

Stüber, K. (1931). Arch. Gewerbepath. Gewerbehyg., 2, 398.

Teare, D. (1948). Brit. med. J., 2, 559.

Times Law Reports, December 1 (1961). London.

von Oettingen, W. F. (1958). Poisoning, 2nd ed., p. 580. Saunders,

Philadelphia.
Willcox, W. (1934). Proc. roy. Soc. Med., 27, 455. 